\title{
Volatile Composition and Antibacterial Activity of Leaves of Chorisia speciosa
}

Farah Kausar ${ }^{1}$, Azeem Intisar ${ }^{*}$, Muhammad Imran Din ${ }^{1}$, Aqsa Aamir ${ }^{1}$, Tajamal Hussain ${ }^{1}$, Pakeeza Aziz $^{1}$, Zeeshan Mutahir ${ }^{2}$, Sahiba Fareed ${ }^{1}$, Baria Samreen ${ }^{1}$, Kashaf Sadaqat ${ }^{1}$

${ }^{1}$ Institute of Chemistry, University of the Punjab, Lahore, Pakistan

${ }^{2}$ Institute of Biochemistry and Biotechnology, University of the Punjab, Lahore, Pakistan.

*Corresponding author: Azeem Intisar, email: azeemintisar.chem@pu.edu.pk, Tel: 00923344160636

Received September $9^{\text {th }}, 2020$; Accepted September $24^{\text {th }}, 2020$.

DOI: http://dx.doi.org/10.29356/jmcs.v64i4.1440

\begin{abstract}
In this study, volatile composition of leaves of Chorisia speciosa was studied first time. The oil was extracted by microwave-assisted oil extraction and constituents were separated and characterized by gas chromatography - mass spectrometry. A yield of $0.21 \%$ was obtained and a total of 25 constituents were identified. Most dominating constituents were: caryophyllene (32.26\%), bicyclogermacrene (9.88\%), humulene $(9.26 \%), \alpha$-selinene $(9.18 \%)$ and $\beta$-elemene $(8.06 \%)$. The anti-bacterial activity of volatile oil was also evaluated against four pathogenic strains. The oil showed different zones of inhibition against different microbes where strongest activity was found against $S$. aureus $(25 \mathrm{~mm})$, moderate activity $(15 \mathrm{~mm})$ against $E$. coli and no activity against $S$. typhi $(9 \mathrm{~mm})$ at the dose value of $3.64 \mathrm{mg}$. The observed antibacterial activity was due to the presence of various biologically active major and minor constituents.
\end{abstract}

Keywords: Chorisia speciosa; volatile oil; sesquiterpenes; antibacterial activity.

Resumen. Se estudian por primera ocasión los componentes volátiles de las hojas de Chorisia speciosa. El aceite fue extraído empleando microondas y sus componentes fueron separados y caracterizados empleando cromatografía de gases-espectrometría de masas. El aceite se obtuvo con un rendimiento del $0.21 \%$ y se identificaron 25 compuestos. Los componentes más abundantes son cariofileno (32.26\%) biciclogermacrano (9.88\%), humuleno (9.26\%), $\alpha$-selineno $(9.18 \%)$ y $\beta$-elemeno. La actividad antibacterial del aceite volátil fue evaluada frente a cuatro colonias de patógenos, mostrando diferentes áreas de inhibición contra diferentes microorganismos, en donde la actividad más intensa la mostró frente $S$. aureus $(25 \mathrm{~mm})$, contra $E$. coli mostró actividad intermedia y no fue activo frente a $S$. typhi $(9 \mathrm{~mm})$ en dosis de $3.64 \mathrm{mg}$. La actividad antimicrobiana observada se debe a la presencia en mayor o menor proporción de varios compuestos bioactivos.

Palabras clave: Chorisia speciosa; aceite volátil; sesquiterpenos; actividad antimicrobiana.

\section{Introduction}

Chorisia speciosa (Silk floss tree) is the member of family Bombacaceae. It is a perennial, deciduous, woody tree, distinguished by its swollen trunk and spiny bark, mostly present in tropical and subtropical regions of the world.[1] Being economical, it is used throughout the world due to its medicinal and commercial importance.[2] Its seeds are a rich source of protein and produce oil which is unsaturated in nature. When stem of the plant suffers from some sort of injury, a gum composed of polysaccharide units, exudates.[3] It has been 
traditionally used in many health issues as fever, diarrhea, diabetes, parasitic infections, ulcer, and rheumatism. It is widely used in medicine as it possessess anti-inflammatory, antioxidant, hepatoprotective and cytotoxic activities.[4] Previously this plant is known to contain flavones, flavonols, anthocyanidins, steroids, tannins, fatty acids, fatty esters and triglycerols, carbohydrates and uronic acids.[1]

Pathogenic microbes are a common cause of various diseases including infectious diseases caused by multi drug resistant microbes. Essential oils are known to possess a strong activity against these microbes including their resistant variants.[5] The aim of this study was to report the volatile composition of Chorisia speciosa and its antimicrobial activity against various pathogenic microbes. To the best of our knowledge, this is the first report on the volatile oil constituents of the leaves of Chorisia speciosa.

\section{Experimental}

\section{Materials and Methods}

\section{Extraction of oil}

Fresh leaves of Chorisia speciosa were collected from Jinnah garden, Lahore, Punjab, Pakistan. The plant was identified by Dr. Abdul Rehman Niazi and voucher specimen (LAH\#0312019) was submitted to the herbarium in Department of Botany, University of the Punjab, Lahore, Pakistan. Fresh leaves were cleaned and $70 \mathrm{~g}$ material was subjected to the microwave-assisted extraction of in a Clevenger type apparatus for 45 minutes using a domestic and modified microwave (Nobel-OM46SS, output frequency: $2450 \mathrm{MHz}$, input voltage: $230 \mathrm{~V} \sim 50 \mathrm{~Hz}$, output voltage: $1000 \mathrm{~W}$,) set at $60 \%$ for regulating temperature. n-Hexane was used as the collecting solvent. The extraction was repeated thrice to attain the maximum quantity of essential oil. The oil was separated from the solvent, placed into a sealed cap vial and stored in the refrigerator at temperature below $-10^{\circ} \mathrm{C}$ for further analysis by gas chromatography - mass spectrophotometry. For antibacterial analysis, the solvent was removed by evaporating it at low temperature.

\section{Gas chromatography- mass spectrometry}

Agilent technologies (Gas chromatograph GC7890B and mass spectrometer MS5977A) was used for the GC-MS analysis. The volatile components of oil were separated in DB-5MS column $(30 \mathrm{~m} \times 250 \mu \mathrm{m}$ ID $\times$ $0.25 \mu \mathrm{m}$ thickness of film). The operation was started at $50{ }^{\circ} \mathrm{C}$ and raised at the rate of $8{ }^{\circ} \mathrm{C} / \mathrm{min}$ to the final temperature of $300{ }^{\circ} \mathrm{C}$ where temperature was sustained for 1 minute. Carrier gas used in this process was Helium, having $1 \mathrm{~mL} / \mathrm{min}$ flow rate. $1 \mu \mathrm{L}$ volume of sample oil was injected in the split mode at the ratio 1:10. The temperature of injector was $260^{\circ} \mathrm{C}$. The temperature ranges for ion source and transfer line was $25^{\circ} \mathrm{C}$ and $300{ }^{\circ} \mathrm{C}$. Volatile oil constituents were identified by comparing their mass spectra with standards provided in NIST-2011 library. Retention indices were calculated by running saturated alkanes $\left(\mathrm{C}_{7}-\mathrm{C}_{30}\right)$ under the same conditions through which the oil was run and compared with the ones cited in literature [6,7] for comparison and hence dual confirmation of compounds was performed. Constituents were arranged in the increasing order of their retention times and retention indices (RI). Their relative abundance was reported using peak area normalization method.

\section{Antibacterial assay}

Three pathogenic strains: Staphylococcus aureus, Escherichia coli and Salmonella typhi were obtained from Jinnah Hospital, Lahore and were characterized prior to activity evaluation by standard Analytical Profile Index method (API). For the evaluation of antibacterial activity of volatile oil of leaves of Chorisia speciosa, agar well diffusion method was used. Media was prepared with Muller Hinton agar. The wells were bored by the sterilized Pasteur pipette and then the bacterial culture was spread over the plates. Plant extract $(10 \mu \mathrm{L}, 20$ $\mu \mathrm{L}$, and $40 \mu \mathrm{L}$ with $0.91 \mathrm{mg}, 1.82 \mathrm{mg}, 3.62 \mathrm{mg}$, respectively) dissolved in n-hexane was poured into these wells. Doxycycline was used as the positive control $(25 \mu \mathrm{g})$. All the plates were placed overnight at $37^{\circ} \mathrm{C}$ and then their zones of inhibition were measured. The method was adopted from a previously published report with minor modifications.[8] 


\section{Results and discussion}

\section{Volatile components of leaves of Chorisia speciosa}

Light yellow oil with a yield of $0.21 \%$ was obtained from the leaves of Chorisia speciosa. A total of 25 compounds constituting a percentage of $93.79 \%$ were successfully identified. The most abundant components were caryophyllene (32.26\%), bicyclogermacrene (9.88\%), humulene $(9.26 \%), \alpha$-selinene $(9.18$ $\%)$ and $\beta$-elemene (8.06 \%) as shown in Fig 1. Mass spectra of these compounds are provided in Fig 2 and a complete list of identified compounds is shown in Table 1. Previously, Chorisia speciosa has been used as a synthetic reserve for various fatty acids including linoleic acid and palmitic acid etc. [9] but this phytochemical profile highlights the potential to isolate industrially important caryophyllene and bicyclogermacrene from the leaf essential oil.

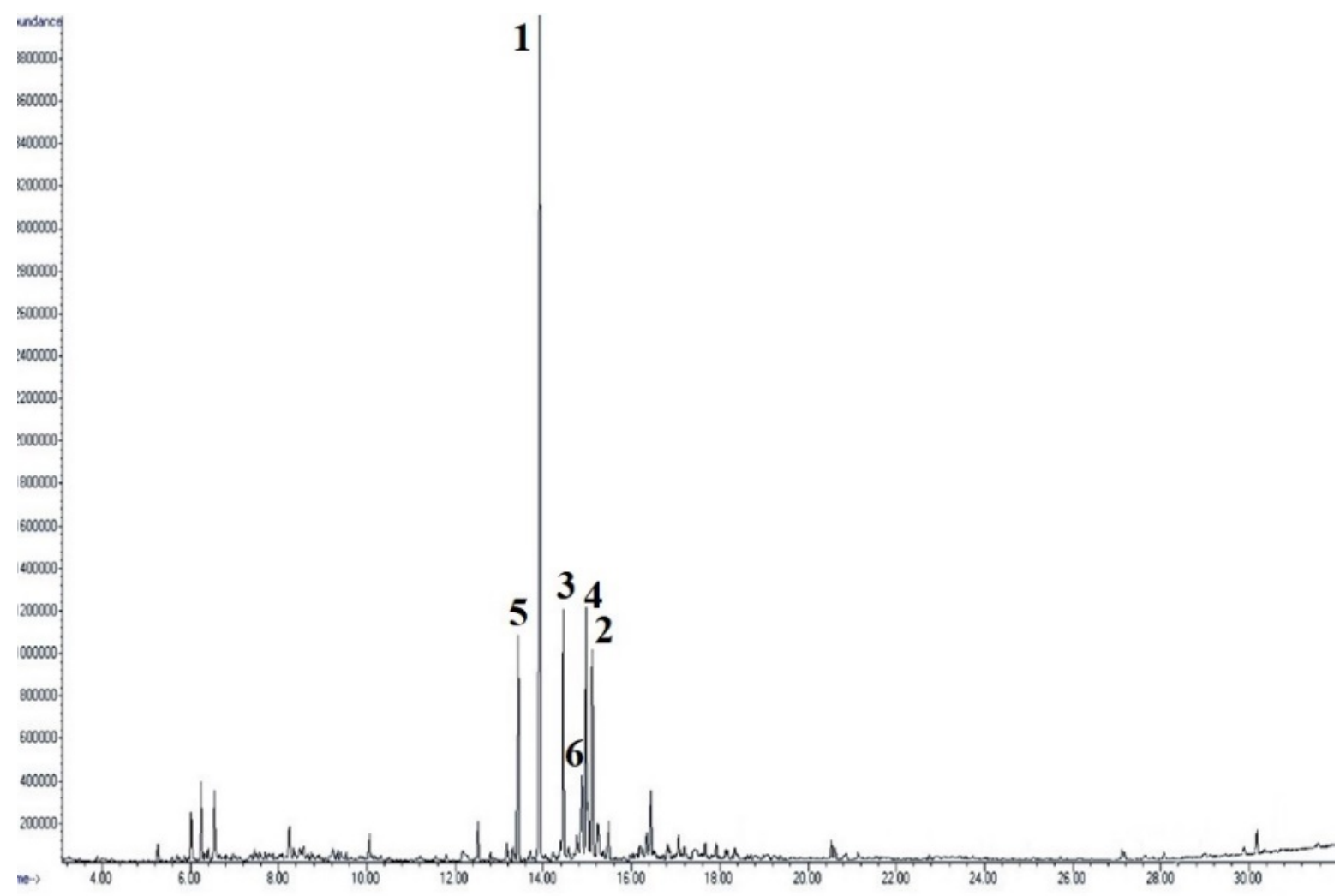

Fig. 1. Total Ion chromatogram of leaf essential oil of Chorisia speciosa. Numbers represent major compounds (1: $\beta$-Elemene, 2: Caryophyllene, 3: Humulene, 4: D-Germacrene 5: $\alpha$-Selinene, 6: Bicyclogermacrene). 

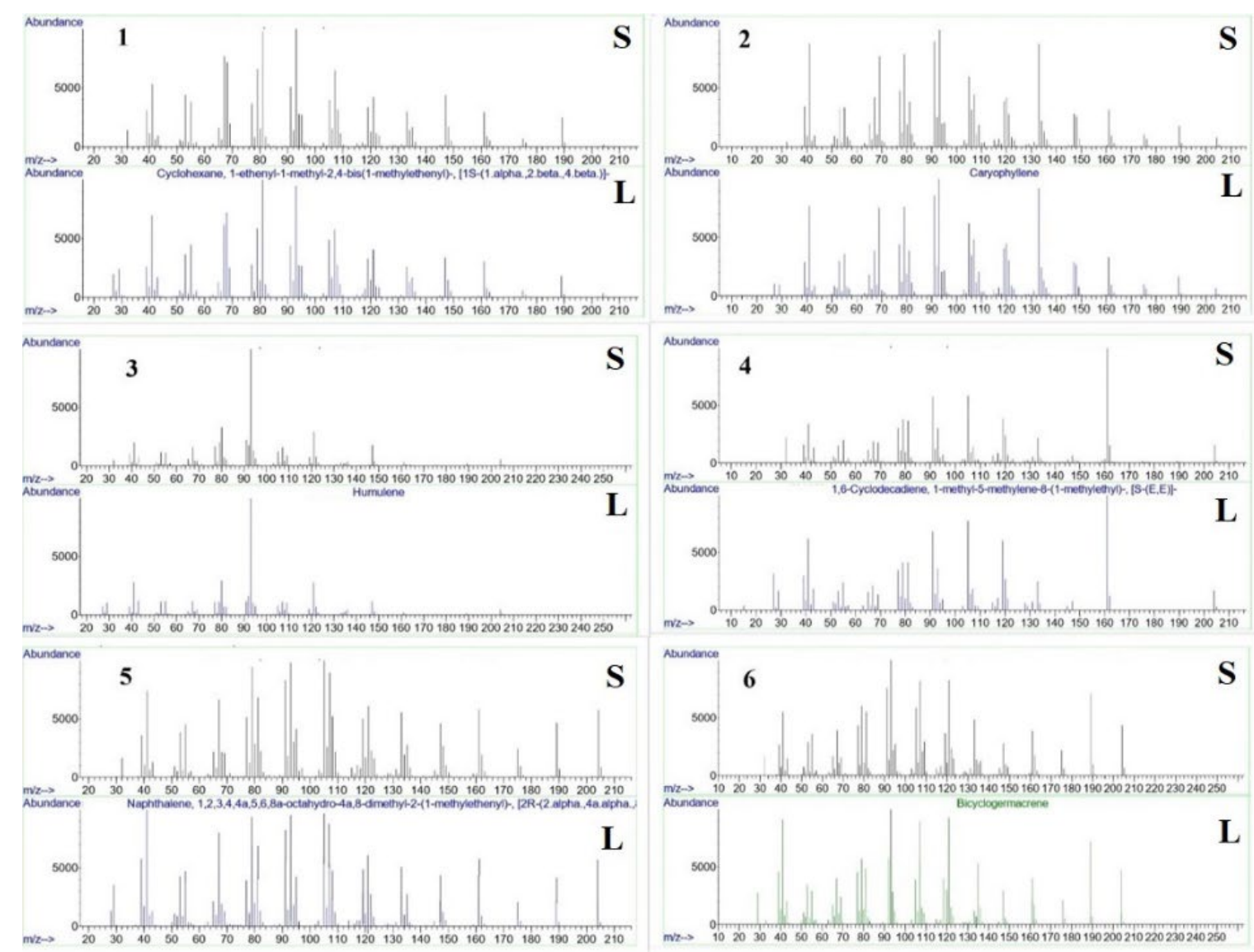

Fig. 2. Mass spectra of six major constituents of leaf oil of Chorisia speciosa having matching similarity with NIST-2011 standards. (1: $\beta$-Elemene, 2: Caryophyllene, 3: Humulene, 4: D-Germacrene 5: $\alpha$-Selinene, 6: Bicyclogermacrene) In all cases, S - Spectra of the compound present in the oil sample, L - Spectra of the compound matched from NIST-2011 library.

Fragmentation patterns and relative mass spectral data of six major compounds identified from essential oil sample, are provided as follows:

Compound No. 1. Caryophyllene: 204(9, $\left.\mathrm{M}^{+}\right), 189(23), 175(12), 161(35), 147(32), 141(4), 133(95)$, 128(3), 120(42), 115(8), 110(4), 105(66), 93(100), 79(85), 69(80), 63(3), 55(36), 50(3), 41(85); Peak match $99 \%$; Second confirmation was performed by Retention Index match (calculated value 1421, literature value 1418).

Compound No. 2. Bicyclogermacrene: 204(46, $\left.\mathrm{M}^{+}\right)$, 189(85), 175(26), 161(43), 147(35), 141(1), 133(55), 115(8), 107(83), 79(68), 67(40), 55(37), 41(59); Peak match $81 \%$; Second confirmation was performed by Retention Index match (calculated value 1499, literature value 1496).

Compound No. 3. Humulene: 204(5, $\left.\mathrm{M}^{+}\right)$, 189(2), 161(4), 147(17), 136(3), 121(29), 115(2), 107(15), 93(100), 80(33), 67(15), 41(23); Peak match $97 \%$; Second confirmation was performed by Retention Index match (calculated value 1452, literature value 1455).

Compound No. 4. $\alpha$-Selinene: 204(65, $\left.\mathrm{M}^{+}\right), 189(50), 175(26), 161(67), 147(49), 133(59), 128(5)$, 121(63), 105(99), 93(98), 79(90), 67(61), 41(73); Peak match; Retention Index match (calculated value, literature value) confirmed it to be $\alpha$-Selinene. 
Compound No. 5. $\beta$-Elemene: 204(2, $\left.\mathrm{M}^{+}\right)$, 189(25), 175(7), 161(29), 147(44), 133(30), 128(9), 121(42), 115(3), 107(65), 93(100), 81(98), 67(77), 53(44), 41(53); Peak match $93 \%$; Retention Index match (calculated value 1385 , literature value 1390) also confirmed it to be $\beta$-Elemene.

Compound No. 6. D-Germacrene are 204(17, $\left.\mathrm{M}^{+}\right), 189(2), 177(6), 161(100), 147(8), 133(27), 119(38)$, 105(58), 91(66), 79(40), 67(21), 55(22), 41(44), 32(34); Peak match $99 \%$; Retention Index match (calculated value 1480 , literature value 1482) also confirmed it to be D-Germacrene.

Caryophyllene is the most abundant component found in essential oil of Chorisia speciosa. It is the member of bicyclic sesquiterpenes, with strong wooden odor and used in cosmetics and food industry.[10] It also shows strong antibacterial activity against various bacterial strains. This compound exhibits more distinct antimicrobial activity against Gram-positive strains than Gram-negative strains. In literature E. coli was found less vulnerable than the other Gram-positive bacterial strains tested. Previous findings have proven its antimicrobial, anticarcinogenic, antioxidant, antibiotic, anti-inflammatory, and local anaesthetic effects.[11] Bicyclogermacrene, the second most abundant compound is a sesquiterpene that is used as a tea flavor due to its sweet herb like odor.[12] It possesses antibacterial, anti-inflammatory, anticancer, antiulcer, and antirheumatic properties [13] where bicyclogermacrene present in Heracleum. sprengelianum leaf oil exhibited exceptional mosquito larvicidal activity on Anopheles subpictus. [14] It is generally observed in Origanum laevigatum, Petroselinum crispum, Laurus nobilis, Coriandrum sativum, Mentha piperita citrata, Melissa officinalis etc. [15] and is the main constituent in the oil of Origanum laevigatum.

Humulene, another significant compound, possesses woody aroma and herbal characters which makes it pleasant for senses.[16,17] It is known for its anticancer activity [18] whereas along with caryophyllene, shows antibacterial activity against $S$. aureus, Pseudomonas aeruginosa, Bacillus subtilis, Escherichia coli, Bacillus sphaericus and Salmonella typhimurium. $[19,20] \alpha$-Humulene is another antibacterial agent [21] and it is also known as an eco-friendly larvicide.[22] Another important constituent, $\beta$-elemene was identified which belongs to the class of elemenes that adds floral aroma to plants and thus used as pheromones by some insects. It has an effective role in the treatment of hyperplastic and proliferative disorders and shows strong inhibition in ovarian cancer cells. [23]

Table 1. Volatile components of leaves of Chorisia speciosa.

\begin{tabular}{|c|c|c|c|c|c|c|}
\hline Sr. No. & $\begin{array}{c}\text { Retentio } \\
\mathbf{n} \\
\text { Time } \\
(\mathbf{m i n})\end{array}$ & $\begin{array}{c}\text { Names of } \\
\text { compounds }\end{array}$ & $\begin{array}{c}\text { Retention } \\
\text { Indices } \\
\text { Calculated } \\
\text { RI }_{(\text {Lit) }}\end{array}$ & $\begin{array}{c}\text { Retention } \\
\text { Indices } \\
\text { Literature } \\
\text { RI }_{(\mathbf{c})}\end{array}$ & $\begin{array}{c}\text { Relative } \\
\text { Abundance } \\
\mathbf{( \% )}\end{array}$ & $\begin{array}{c}\text { Identification } \\
\text { Methods }\end{array}$ \\
\hline 1. & 3.23 & Hexanal & 800 & 798 & 0.24 & MS, RI \\
\hline 2. & 5.25 & $\alpha$-Pinene & 931 & 930 & 0.59 & MS, RI \\
\hline 3. & 6.02 & $\beta$-Pinene & 975 & 973 & 1.56 & MS, RI \\
\hline 4. & 6.25 & $\beta$-Myrcene & 988 & 986 & 2.56 & MS, RI \\
\hline 5. & 6.53 & $\begin{array}{c}3 \text {-Hexen-1-ol, } \\
\text { acetate, (Z)- }\end{array}$ & 1005 & 1002 & 2.60 & MS, RI \\
\hline 6. & 8.35 & Nonanal & 1102 & 1100 & 0.67 & MS, RI \\
\hline 7. & 11.55 & $\begin{array}{c}\text { p- } \\
\text { Ethylguaiacol }\end{array}$ & 1280 & 1278 & 0.44 & MS, RI \\
\hline 8. & 12.52 & $\delta$-EIemene & 1324 & 1323 & 1.54 & MS, RI \\
\hline
\end{tabular}




\begin{tabular}{|c|c|c|c|c|c|c|}
\hline 9. & 13.18 & $\alpha$-Copaene & 1370 & 1375 & 0.68 & MS, RI \\
\hline 10 . & 13.43 & $\beta$-Elemene & 1385 & 1390 & 8.06 & MS, RI \\
\hline 11. & 13.92 & Caryophyllene & 1418 & 1421 & 32.26 & MS, RI \\
\hline 12. & 14.39 & $\beta$-Farnesene & 1448 & 1451 & 0.89 & MS, RI \\
\hline 13. & 14.45 & Humulene & 1452 & 1455 & 9.26 & $\mathrm{MS}, \mathrm{RI}$ \\
\hline 14. & 14.57 & $\begin{array}{c}\text { Alloaromaden } \\
\text { drene }\end{array}$ & 1462 & 1462 & 0.65 & MS, RI \\
\hline 15. & 14.87 & D-Germacrene & 1480 & 1482 & 3.40 & MS, RI \\
\hline 16. & 14.97 & $\alpha$-Selinene & 1488 & 1488 & 9.18 & $\mathrm{MS}, \mathrm{RI}$ \\
\hline 17. & 15.10 & $\begin{array}{l}\text { Bicyclogerma } \\
\text { crene }\end{array}$ & 1499 & 1496 & 9.88 & MS, RI \\
\hline 18. & 15.23 & $\beta$-Bisabolene & 1506 & 1505 & 1.74 & MS, RI \\
\hline 19. & 15.36 & $\gamma$-Muurolene & 1515 & 1513 & 0.46 & $\mathrm{MS}, \mathrm{RI}$ \\
\hline 20. & 15.48 & $\delta$-Cadinene & 1525 & 1522 & 1.99 & MS, RI \\
\hline 21. & 16.34 & Spathulenol & 1582 & 1579 & 0.92 & MS, RI \\
\hline 22. & 16.44 & $\begin{array}{c}\text { Caryophyllene } \\
\text { oxide }\end{array}$ & 1589 & 1586 & 2.59 & MS, RI \\
\hline 23. & 17.20 & $\begin{array}{l}\text { Isoaromadendr } \\
\text { ene epoxide }\end{array}$ & 1594 & 1639 & 0.71 & MS, RI \\
\hline 24. & 17.39 & $\beta$-Selinenol & 1649 & 1653 & $\mathrm{~T}$ & MS, RI \\
\hline 25 . & 30.17 & Supraene & 2823 & 2815 & 0.92 & MS, RI \\
\hline
\end{tabular}

Total $=93.79 \%, \mathrm{MS}=$ Mass spectrometer, $\mathrm{RI}_{(\mathrm{Lit})}=$ Retention indices obtained from Adams \& NIST online database, $\mathrm{RI}_{(\mathrm{c})}$ $=$ Retention indices calculated relative to $\mathrm{C}_{7}-\mathrm{C}_{30}$ authentic standards under same conditions used for essential oil analysis.

The compounds are classified in Table 2 which represents sesquiterpenes, oxygenated sesquiterpenes and monoterpenes being the most dominating classes with $79.99 \%, 4.22 \%$ and $4.71 \%$. Sesquiterpenes, known to exhibit strong antimicrobial activity [24-26] along with anti-tumor and anti-inflammatory activities [27], was the most dominating class having numerous active compounds such as caryophyllene, humulene, bicyclogermacrene etc. Caryophyllene and its oxides mainly belong to sesquiterpenes and possess strong antiinflammatory, antifungal and cytotoxic activities along with antimicrobial potential. [28] Oxygenated sesquiterpenes was the second most abundant class comprising various active constituents including caryophyllene oxide [29], spathulenol [30], $\beta$-Selinenol [31] etc. Monoterpenes being the third major class also 
include active constituents such as $\alpha$-Pinene, $\beta$-Pinene [32] and $\beta$-Myrcene. [33] $\alpha$-pinene and $\beta$-pinene are known to inhibit the growth of potential infectious gram-positive bacteria causing endocarditis. [34]

Table 2. Classification of different volatile constituents.

\begin{tabular}{|c|c|c|}
\hline $\begin{array}{c}\text { Class of Volatile } \\
\text { Constituents }\end{array}$ & Serial Number of the Constituents & $\begin{array}{c}\text { Percentage } \\
\text { (\%) }\end{array}$ \\
\hline Monoterpenes & $2,3,4$ & 4.71 \\
\hline Sesquiterpenes & $8,9,10,11,12,13,14,15,16,17,18,19,20$ & 79.99 \\
\hline Oxygenated sesquiterpenes & $21,22,23,24$ & 4.22 \\
\hline Aldehydes & 1,6 & 0.91 \\
\hline Others & $5,7,25$ & 3.96 \\
\hline & Total & 93.79 \\
\hline
\end{tabular}

\section{Antibacterial activity}

In general, oils are hydrophobic in nature and cause deadly effects in terms of permeability and protonmotive force on cell membranes [35] that ultimately results in ion leakage; hence membrane permeability is key factor in this regard. [36] Previously methanol extract of Chorisia speciosa has been reported to possess antimicrobial potential against $B$. cereus, $S$. aureus, $P$. aeruginosa, K. pneumonia, S. enteric and hexane extract of this species is also active against $E$. coli. Besides antimicrobial activity, this plant has been reported for its antipyretic and anti-inflammatory activities. [37] Its fixed oil is known to exert anti-obesity and hypoglycaemic effects which suggests the use of its edible oil in preventing obesity and related disorders. [9] In this study, antibacterial evaluation of essential oil of Chorisia speciosa against three pathogenic microbes was evaluated and it showed highest activity against $S$. aureus $(25 \mathrm{~mm})$, and then against $E$. coli $(15 \mathrm{~mm})$ whereas no activity was found against $S$. typhi at the dose level of $3.64 \mathrm{mg}$ presenting its stem potential as shown in Table 3 . However, in comparison, the positive control showed a strong activity at a dose value of $25 \mu \mathrm{g}$ against $S$. aureus $(27 \mathrm{~mm})$, S. typhi $(22 \mathrm{~mm})$ and E. coli $(20 \mathrm{~mm})$, hence the essential oil activity was considered as moderate against $S$. aureus and weak against $E$. coli, taking into account the difference in dose values and their zones of inhibition.

The main reason behind this activity may obviously be the presence of sesquiterpenes along with other classes.[38,39] Hence, in future, this oil may possibly prove to be important in treating diseases caused by these microbes such as osteomyelitis, endocarditis, abscesses, bloodstream infections, and diarrhea etc., along with other diseases. Higher activity against $S$. aureus may be attributed to the presence of caryophyllene, [38,40,41] where it has also shown activity against $E$. coli.[41,42] Caryophyllene was found to be more effective as compared to standard drug, kanamycin against $S$. aureus and $P$. aeruginosa, and exhibited promising activity against K. pneumoniae, E. coli, [38] S. sobrinus, S, salivarius, S. sanguinis, S. mutans [43], Enterococcus faecalis, Proteus vulgaris, Salmonella abony [41], S. epidermidis, S. typhimurium [42] and B. subtilis.[40] Bicyclogermacrene was active against S. aureus (MIC $292 \mu \mathrm{g} / \mathrm{mL}$ ) and E. coli. [44] Humulene isolated from the essential oil of Abies balsamea was also active against $S$. aureus and E. coli [19] MIC of $\alpha$-humulene for Bacteroidid fragilis came out to be $2 \mu \mathrm{g} / \mathrm{mL}$ [45] and is also active towards P. aeruginosa and B. cereus. [21] Caryophyllene and D-germacrene exhibit their activity against various strains including $S$. aureus and E. coli (MIC $125-250 \mu \mathrm{g} / \mathrm{mL}$ ) which is higher than streptomycin.[46] D-germacrene showed an MIC value of $30.33 \mu \mathrm{g} / \mathrm{mL}$ against $S$. aureus.[47] $\beta$-elemene also showed promising activity against $S$. aureus along with Propionibacterium acnes and Maiassezia furfur with an MIC value of $125 \mu \mathrm{g} / \mathrm{mL}$.[48] On the other hand, numerous minor constituents of essential oil are also known for their significant potential especially $\alpha$-pinene which exhibited significant activity against $S$. aureus and E. coli.[34,49] $\gamma$-Muurolene is responsible for strong inhibition of $E$. coli growth and caryophyllene oxide is active towards many bacterial strains including S. aureus and $E$. coli. [50,51] A number of these active constituents have imparted their role either individually or in synergy to produce the resultant activity. However, the difference in the activity was obviously due to difference in the mode of action of oil against different bacteria due to the difference in their genetic and cell wall makeup 
and the fact that drugs target at different sites. Moreover, the lower activity against gram-negative bacteria attributes to the lower vulnerability of these microbes towards volatile oils, since they hold a layer of lipopolysaccharide wrapping around the cell wall that hampers the penetration of hydrophobic compounds.[52]
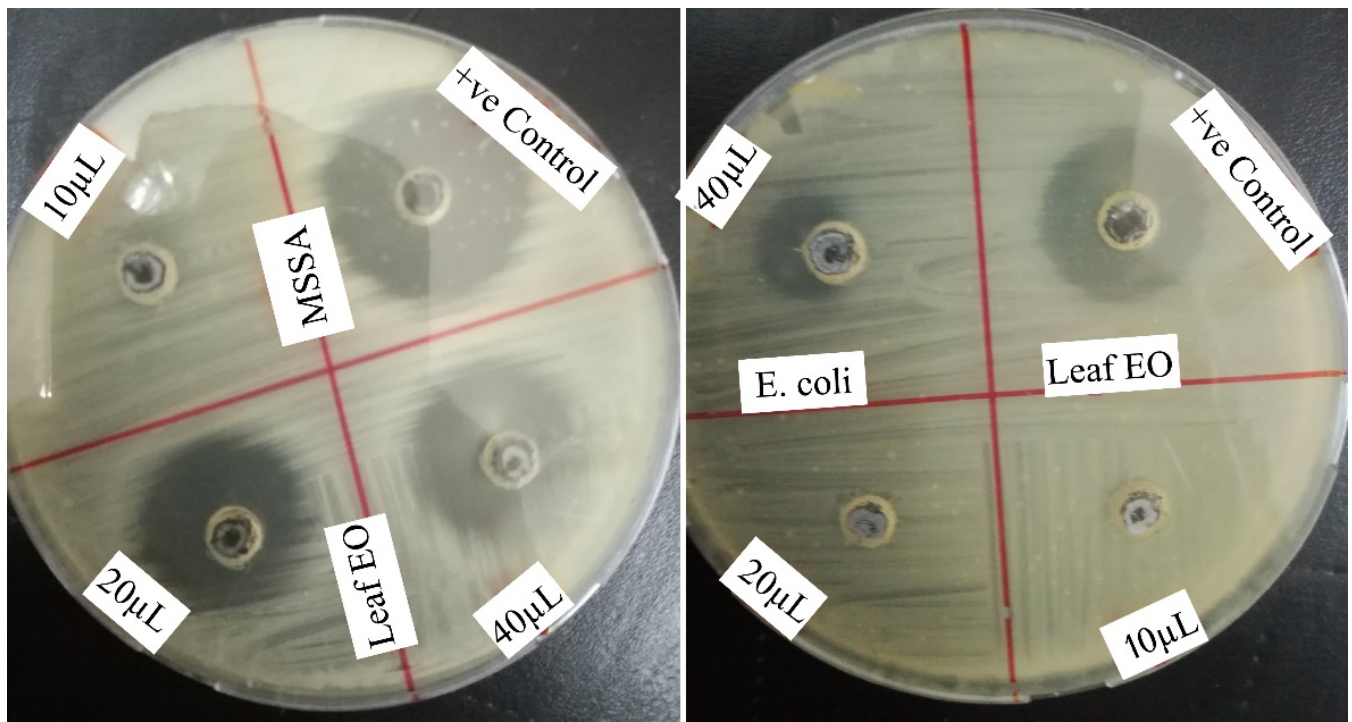

Fig. 3. Antibacterial activity of oil against various strains.

Table 3. Antibacterial activity of oil against various strains.

\begin{tabular}{|c|c|c|c|c|}
\hline \multirow{4}{*}{$\begin{array}{l}\text { Test micro } \\
\text { organisms }\end{array}$} & \multicolumn{3}{|c|}{ Different concentrations of dissolved oil $(91 \mathrm{mg} / \mathrm{mL})$} & \multirow{3}{*}{$\begin{array}{c}\text { (Doxycycline) } \\
25 \mu \mathrm{g}\end{array}$} \\
\hline & $10 \mu \mathrm{L}$ & $20 \mu \mathrm{L}$ & $40 \mu \mathrm{L}$ & \\
\hline & $(0.91 \mathrm{mg})$ & $(1.82 \mathrm{mg})$ & $(3.64 \mathrm{mg})$ & \\
\hline & \multicolumn{4}{|c|}{ Zones of inhibition (mm) } \\
\hline E.coli & 12 & 13 & 15 & 20 \\
\hline S. typhi & 00 & 00 & 00 & 22 \\
\hline S. aureus & 11 & 23 & 25 & 27 \\
\hline
\end{tabular}

\section{Conclusions}

Essential oil compoosition of leaves of Chorisia speciosa led to the identification of 25 components including caryophyllene (32.26\%), bicyclogermacrene (9.88 \%), humulene $(9.26 \%)$, $\alpha$-selinene $(9.18 \%)$ and $\beta$-elemene $(8.06 \%)$ as major constituents. Major part of the composition belonged to sesquiterpenes that possess numerous pharmacological properties including antimicrobial activity. Essential oil showed moderate activity against $S$. aureus and weak activity against $E$. coli whereas no activity was observed against $S$. typhi. Future studies may be performed to further explore the antimicrobial potential of this essential oil.

\section{Acknowledgments}

Authors extend their thanks to University of the Punjab, Pakistan for financial support. 


\section{References}

1. Refaat, J.; Desoky, S.Y.; Ramadan, M.A.; Kamel, M.S., Pharm. Biol. 2013, 51, 100-130.

2. Khan, A.; Saeed, M.; Chaudhary, M.A., Int. J. Biol. Pharm. Allied Sci. 2015, 4, 6826-6838.

3. Beleski-Carneiro, E.; Ganter, J.; Reicher, F., Int. J. Biol. Macromol. 1999, 26, 219-224.

4. Nasr, E.M.; Assaf, M.H.; Darwish, F.M.; Ramadan, M.A., J. Pharmacogn. Phytochem. 2018, 7, 649656.

5. Dorman, H.; Deans, S.G., J. Appl. Microbiol. 2000, 88, 308-316.

6. RP Adams, O.S.-. J. Am. Soc. Mass Spectrom. 2007.

7. NIST, https://webbook.nist.gov/chemistry/.

8. Bano, S.; Intisar, A.; Rauf, M.; Ghaffar, A.; Yasmeen, F., et al., Nat. Prod. Res. 2020, 34, 13111314.

9. Rosselli, S.; Tundis, R.; Bruno, M.; Leporini, M.; Falco, T., et al., Molecules 2020, 25, 1037.

10. Fidyt, K.; Fiedorowicz, A.; Strządała, L.; Szumny, A., Cancer Med. 2016, 5, 3007-3017.

11. Tan, W.-N.; Tan, Z.-H.; Zulkifli, N.I.; Nik Mohamed Kamal, N.N.S.; Rozman, N.A.S., et al., Nat. Prod. Res. 2019, 1-5.

12. Song, H.; Sawamura, M.; Ito, T.; Kawashimo, K.; Ukeda, H., Flav. Fragr. J. 2000, 15, 245-250.

13. Goren, A.C., Rec. Nat. Prod. 2014, 8, 71.

14. Govindarajan, M.; Benelli, G., Ecotoxicol. Environ. Saf. 2016, 133, 395-402.

15. Duke, J., Agric. Res. Service Accessed April 27 (2004).

16. Nance, M.R.; Setzer, W.N., J. Brewing Distill. 2011, 2, 16-22.

17. Peacock, V.E.; Deinzer, M.L., J. Am. Soc. Brewing Chemists 1981, 39, 136-141.

18. Legault, J.; Pichette, A., J. Pharm. Pharmacol. 2007, 59, 1643-1647.

19. Pichette, A.; Larouche, P.L.; Lebrun, M.; Legault, J., Phytother. Res.: An Int. J. Devoted Pharmacol. Toxicol. Eval. Nat. Prod. Derivat. 2006, 20, 371-373.

20. Shafi, P.; Rosamma, M.; Jamil, K.; Reddy, P., Fitoterapia 2002, 73, 439-441.

21. Schmidt, J.M.; Noletto, J.A.; Vogler, B.; Setzer, W.N., J. Herbs, Spices Med. Plants 2007, 12, 43-65. 22. Govindarajan, M.; Benelli, G., Parasitol. Res. 2016, 115, 2771-2778.

23. Li, Q.Q.; Wang, G.; Huang, F.; Banda, M.; Reed, E., J. Pharm. Pharmacol. 2010, 62, 1018-1027.

24. Buckle, J., Clin. Aromather. 2015, 37-72.

25. Sieniawska, E.; Sawicki, R.; Golus, J.; Swatko-Ossor, M.; Ginalska, G., et al., Molecules 2018, 23, 256.

26. Rahman, M.M.; Garvey, M.; Piddock, L.J.; Gibbons, S., Phytotherapy Research: An Int. J. Devoted Pharmacol. Toxicol. Eval. Nat. Prod. Derivat. 2008, 22, 1356-1360.

27. Sabulal, B.; Dan, M.; Kurup, R.; Pradeep, N.S.; Valsamma, R.K., et al., Phytochem. 2006, 67, 24692473.

28. Liu, X.-Y.; Chen, X.-b.; Chen, G.-y., Chem. Indust. Forest Prod. $2012,1$.

29. Couladis, M.; Chinou, I.; Tzakou, O.; Loukis, A., Phytother. Res.: An Int. J. Devoted Pharmacol. Toxicol. Eval. Nat. Prod. Derivat. 2002, 16, 723-726.

30. do Nascimento, K.F.; Moreira, F.M.F.; Santos, J.A.; Kassuya, C.A.L.; Croda, J.H.R., et al., J. Ethnopharmacol. 2018, 210, 351-358.

31. Costa, E.V.; Teixeira, S.D.; Marques, F.A.; Duarte, M.C.; Delarmelina, C., et al., Phytochem. 2008, 69, 1895-1899.

32. Silva, A.C.R.d.; Lopes, P.M.; Azevedo, M.M.B.d.; Costa, D.C.M.; Alviano, C.S., et al., Molecules 2012, 17, 6305-6316.

33. Koutsoudaki, C.; Krsek, M.; Rodger, A., J. Agric. Food Chem. 2005, 53, 7681-7685. 
34. Leite, A.M.; Lima, E.d.O.; Souza, E.L.d.; Diniz, M.d.F.F.M.; Trajano, V.N., et al., Rev. Bras. Cienc. Farmaceut. 2007, 43, 121-126.

35. Tassou, C.; Koutsoumanis, K.; Nychas, G.-J., Food Res. Int. 2000, 33, 273-280.

36. Burt, S., Int. J. Food Microbiol. 2004, 94, 223-253.

37. Khan, A.; Asadsaeed, M.; Chaudhary, M.A.; Ahmad, Q.; Ansari, F., Int. J. Biol. Pharm. Allied Sci 2015, 4, 6826-6838.

38. Dahham, S.S.; Tabana, Y.M.; Iqbal, M.A.; Ahamed, M.B.; Ezzat, M.O., et al., Molecules 2015, 20, 11808-11829.

39. Barrero, A.F.; del Moral, J.F.Q.; Lara, A.; Herrador, M.M., Planta Med. 2005, 71, $67-71$.

40. Öztürk, M.; Duru, M.E.; Aydoğrmuş-Öztürk, F.; Harmandar, M.; Mahlıçlı, M., et al., Nat. Prod. Commun. 2009, 4, $1934578 X 0900400124$.

41. Schmidt, E.; Bail, S.; Friedl, S.M.; Jirovetz, L.; Buchbauer, G., et al., Nat. Prod. Commun. 2010, 5 , $1934578 X 1000500906$.

42. Kılıç, T., Z. Naturforsch. C. 2006, 61, 324-328.

43. Freires, I.A.; Denny, C.; Benso, B.; De Alencar, S.M.; Rosalen, P.L., Molecules 2015, 20, 73297358.

44. Santos, T.G.; Dognini, J.; Begnini, I.M.; Rebelo, R.A.; Verdi, M., et al., J. Brazil. Chem. Soc. 2013, 24, 164-170.

45. Jang, H.-I.; Rhee, K.-J.; Eom, Y.-B., Can. J. Microbiol. 2020, 66, 1-11.

46. Hsouna, A.B.; Halima, N.B.; Abdelkafi, S.; Hamdi, N., J. Oleo Sci. 2013, 62, 973-980.

47. Rather, M.A.; Dar, B.A.; Dar, M.Y.; Wani, B.A.; Shah, W.A., et al., Phytomedicine. 2012, 19, 1185 1190.

48. Zhu, J.; Lower-Nedza, A.D.; Hong, M.; Jiec, S.; Wang, Z., et al., Nat. Prod. Commun. 2013, 8, $1934578 X 1300800430$.

49. Ojeda-Sana, A.M.; van Baren, C.M.; Elechosa, M.A.; Juárez, M.A.; Moreno, S., Food Cont. 2013, 31, 189-195.

50. Perigo, C.V.; Torres, R.B.; Bernacci, L.C.; Guimarães, E.F.; Haber, L.L., et al., Ind. Crop Prod. 2016, 94, 528-539.

51. Vagionas, K.; Graikou, K.; Chinou, I.; Runyoro, D.; Ngassapa, O., J. Essent. Oil Res. 2007, 19, 396400.

52. Moreno, P.R.H.; Lima, M.E.L.; Caruzo, M.B.R.; Torres, D.S.C.; Cordeiro, I., et al., J. Essent. Oil Res. 2009, 21, 190-192. 